\title{
UPAYA PENCEGAHAN RISIKO PASIEN JATUH DI RAWAT INAP
}

\author{
Maharani Zarah ${ }^{1 *}$, Achmad Djunawan ${ }^{1}$ \\ ${ }^{1}$ Administrasi Rumah Sakit STIKES Yayasan Rumah Sakit Dr. Soetomo \\ *Corresponding author: maharanizarah24@gmail.com
}

\begin{abstract}
Patient safety is one of the important things that need to be considered in nursing care in hospitals. Patient safety consists of 6 goals from the six patient safety goals, the incidence offalls is still a worrying thing for all inpatients in hospitals. Prevention efforts can be carried out by obediently carrying out an assessment and preventing the risk of falling in accordance with the high score of the patient's low risk. This literature review study aims to find out how to prevent the risk of falling patients in inpatient care. The method used is a literature review approach with survey paper techniques, searching for journal databases and relevant library sources. This literature review study was obtained from searching research articles from 2011-2020 using Goggle Scholar, Garuda and One Search. There are 10 journals that match the inclusion criteria and according to the research question. The population is inpatient nurses in hospitals. The results based on 10 research journals showed that 9 hospitals with the majority of nurses were obedient in carrying out a patient fall risk assessment and 1 hospital the majority of nurses were not obedient. And efforts to prevent the risk of falling patients have been carried out in hospitals.
\end{abstract}

Keywords: assessment, fall risk, hospitalization

\section{PENDAHULUAN}

Keselamatan Pasien Rumah Sakit (KPRS) merupakan sistem pelayanan di rumah sakit yang dapat memberikan rasa aman kepada pasien dalam memberikan asuhan kesehatan ${ }^{1}$. keselamatan pasien terdiri dari 6 sasaran, dari keenam sasaran keselamatan pasien tersebut kejadian jatuh masih menjadi hal yang mengkhawatirkan pada seluruh pasien rawat inap di rumah sakit ${ }^{2}$. Pasien jatuh merupakan insiden di rumah sakit yang paling mengkhawatirkan dan berdampak pada cidera pasien bahkan kematian dan menjadi adverse event kedua terbanyak dalam perawatan kesehatan setelah kesalahan pengobatan ${ }^{3}$.

Insiden jatuh ini tidak hanya berdampak pada cedera, namun juga meningkatkan lama rawatan, serta biaya rawatan pasien. Pasien cedera dapat mengakibatkan penambahan lama rawatan di rumah sakit selama 6,3 hari rawatan ${ }^{4}$. Di Amerika Serikat insiden jatuh di rumah sakit dan pusat kesehatan dilaporkan sebanyak 1.000 pasien per harinya. Dari 345.800 kejadian jatuh yang terjadi di ruang rawat inap selama penelitian, 315.817 orang dilaporkan mengalami cedera ${ }^{5}$. Perhimpunan Rumah Sakit (PERSI) di Indonesia melaporkan bahwa kejadian pasien jatuh tercatat sebanyak 34 kasus atau setara $14 \%$ insiden jatuh di Rumah Sakit JCI menyatakan bahwa sebuah rumah sakit memerlukan elemen penilaian untuk mengurangi risiko jatuh ${ }^{6}$.

Risk Assessment pasien jatuh merupakan elemen pertama pada program pengurangan risiko jatuh, suatu metode penilaian risiko untuk pasien jatuh yang dilakukan oleh perawat. Risk Assessment pasien jatuh bertujuan memberikan perhatian khusus pada pasien yang berisiko untuk jatuh. Risk Assesment jatuh pada pasien dilakukan pada saat pasien pertama kali masuk rumah sakit (Assessment awal) dan ketika pasien mengalami perubahan status klinik akibat dari perawatan maupun pengobatan selama di rumah sakit ${ }^{7}$.

Upaya pencegahan risiko pasien jatuh untuk mengurangi angka insiden jatuh pada pasien di rawat inap. Pencegahan risiko pasien jatuh yaitu dengan penilaian awal risiko jatuh, penilaian berkala setiap ada perubahan kondisi pasien, serta melaksanakan langkah-langkah pencegahan pada pasien berisiko jatuh. Implementasi di rawat inap berupa proses identifikasi dan penilaian pasien dengan risiko jatuh serta memberikan tanda identitas khusus kepada pasien tersebut, misalnya gelang kuning, memberikan penanda risiko, merendahkan tempat tidur pasien, pemasangan pengaman tempat tidur pasien serta informasi tertulis kepada pasien atau keluarga pasien ${ }^{8}$. Meskipun upaya pencegahan risiko pasien jatuh sudah dilakukan akan tetapi masih ada beberapa rumah sakit yang mengalami insiden pasien jatuh khususnya di rawat inap.

Berdasarkan data dari Komite Mutu dan Manajemen Risiko RSUP Dr. M. Djamil Padang, pada tahun 2018 terdapat 53 insiden keselamatan pasien. Insiden pasien jatuh merupakan insiden terbanyak dengan 11 kasus ${ }^{9}$. Hal ini tentunya menjadi penting untuk dilakukan penelitian lebih dalam karena masih tingginya angka insiden jatuh dan masih terdapat perawat yang tidak melaksanakan assessment risiko jatuh, yang mana hal tersebut penting dilakukan sebagai upaya pencegahan risiko pasien jatuh. Maka penulis tertarik untuk meneliti bagaimana upaya penegahan risiko pasien jatuh dii rawat inap.

\section{METODE PENELITIAN}

Desain penelitian ini adalah Literatur Review atau tinjaun pustaka. Studi Literatur Review merupakan penelitian yang dilakukan oleh peneliti 


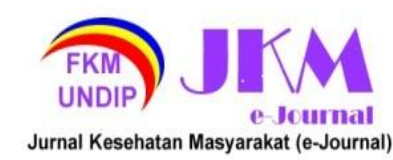

dengan melakukan pencarian terhadap database jurnal dan sumber pustaka yang relevan dengan menggunakan Google Scholar,Garuda dan One Search. Kriteria Inklusi yang digunakan adalah Terpublikasi pada 2011-2021, Baha Indonesia, full text, open access dan tema isi artikel Risiko Jatuh dan Risk Assessment di rawat inap.

Tahap Penelusuran ini menjelaskan tentang bagaimana cara penulis melakukan penelusuran naskah yang akan digunakan sebagai bahan dalam literatur review. Tahapan penelusuran ini dimulai dengan penentuan keyword/kata kuncipenelusuran kemudian dijelaskan secara tekstual dan digambarkan dalam bentuk diagram alur. Diagram alur literatur Review sebagai berikut:

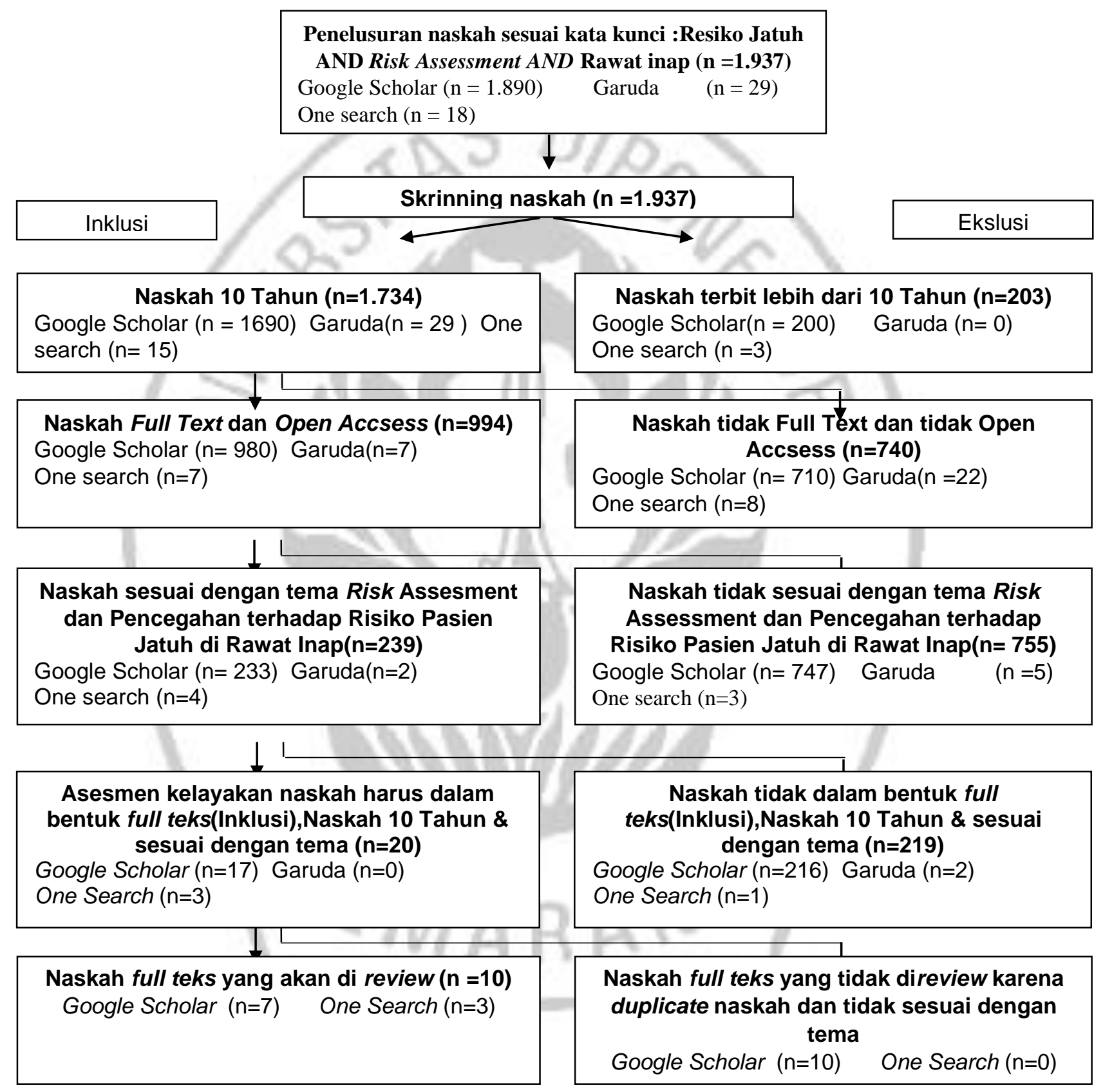

Gambar 1. Diagram Alur Literatur Review 


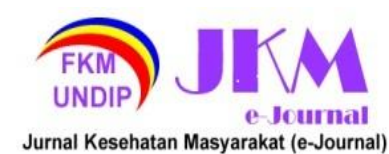

Hasil Dan Pembahasan

Pelaksanaan Risk Assessment pasien jatuh di rawat inap

Risk Assessment pasien jatuh merupakan langkah awal untuk mencegah terjadinya jatuh pada pasien, apabila tidak dilakukan maka insiden jatuh
JURNAL KESEHATAN MASYARAKAT (e-Journal)

Volume 10, Nomor 1, Januari 2022

ISSN: 2715-5617 / e-ISSN: 2356-3346

http://ejournal3.undip.ac.id/index.php/ikm

Tabel 1. Hasil Kepatuhan Pelaksanaan Assessment dari 10 jurnal

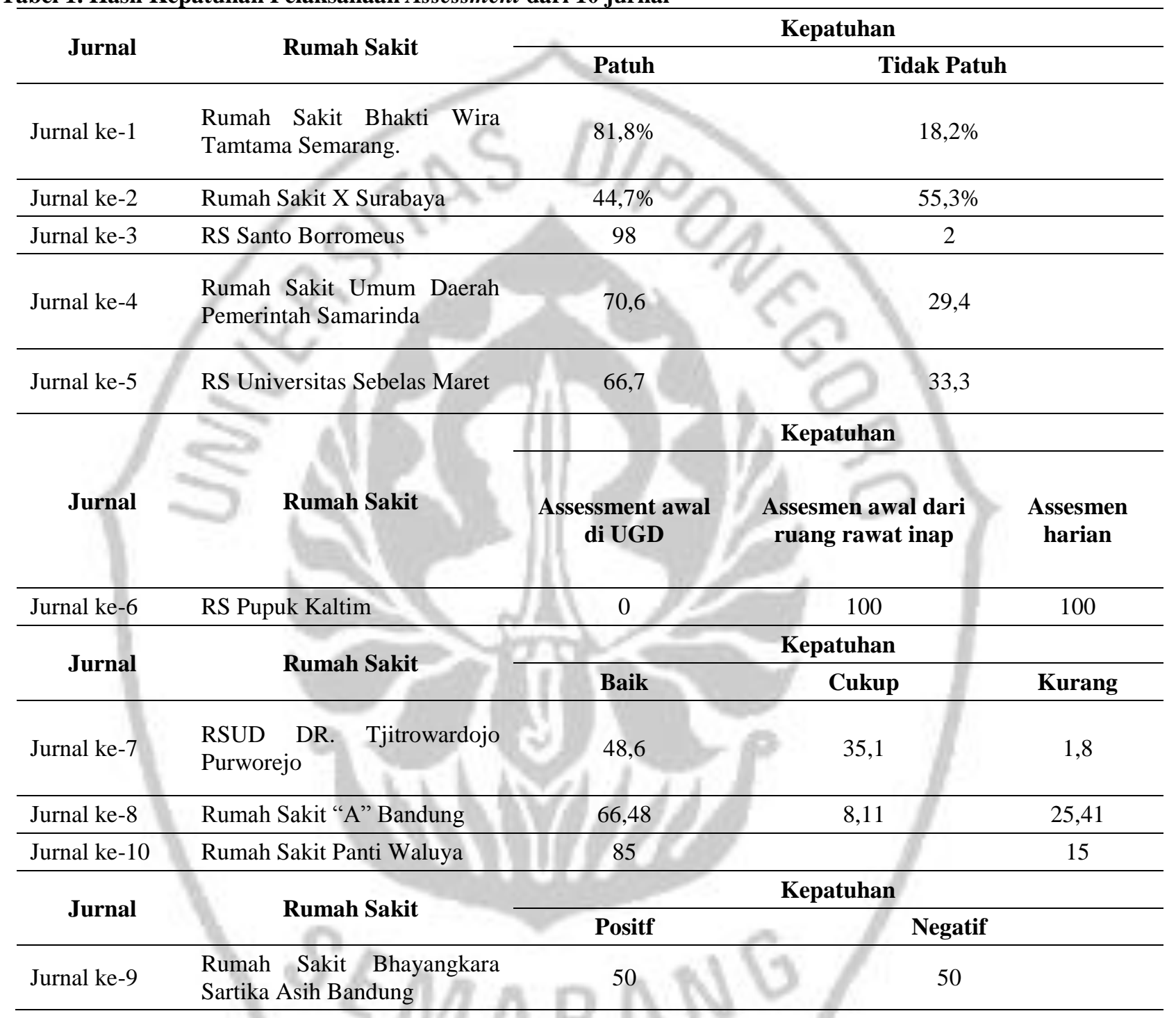

Tabel 1. Merupakan hasil kepatuhan pelaksanaan Risk Assessment di rawat inap. Variable yang digunakan untuk mengkategorikan kepatuhan berbeda - beda. 5 jurnal menggunakan variable patuh dan tidak patuh, 1 jurnal menggunakan variable Assessment awal di UGD dan Assessment awal di rawat inap, 3 Jurnal menggunakan variable baik, cukup dan kurang dan 1 jurnal menggunakan variable positif dan negative. Variabel yang berbeda - beda menyulitkan peneliti dalam menganalisa hasil, maka dari itu penulis mengekuivalen menjadi akan terjadi ${ }^{10}$. Kepatuhan dalam Assessment resiko jatuh yang dilakukan perawat dapat menurunkan angka insiden pasien jatuh di rumah sakit. Berdasarkan 10 jurnal yang direview hasil kepatuhan pelaksanaan assessment sebagai berikut : 


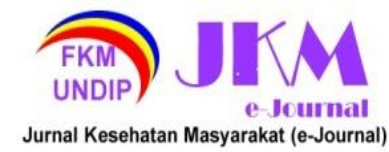

\author{
JURNAL KESEHATAN MASYARAKAT (e-Journal) \\ Volume 10, Nomor 1, Januari 2022 \\ ISSN: 2715-5617 / e-ISSN: 2356-3346 \\ http://ejournal3.undip.ac.id/index.php/ikm
}

Tabel 2. Hasil Kepatuhan Pelaksanaan Assessment dari 10 jurnal

\begin{tabular}{|c|c|c|c|c|}
\hline \multirow{2}{*}{ Jurnal } & \multirow{2}{*}{ Rumah Sakit } & \multicolumn{3}{|c|}{ Kepatuhan } \\
\hline & & Patuh & Cukup Patuh & Tidak Patuh \\
\hline Jurnal ke-1 & $\begin{array}{l}\text { Rumah Sakit Bhakti Wira Tamtama } \\
\text { Semarang. }\end{array}$ & $81,8 \%$ & - & $18,2 \%$ \\
\hline Jurnal ke-2 & Rumah Sakit X Surabaya & $44,7 \%$ & - & $55,3 \%$ \\
\hline Jurnal ke-3 & RS Santo Borromeus & $98 \%$ & - & $2 \%$ \\
\hline Jurnal ke-4 & $\begin{array}{l}\text { Rumah Sakit Umum Daerah } \\
\text { Pemerintah Samarinda }\end{array}$ & $70,6 \%$ & - & $29,4 \%$ \\
\hline Jurnal ke-5 & RS Universitas Sebelas Maret & $66,7 \%$ & - & $33,3 \%$ \\
\hline Jurnal ke-6 & RS Pupuk Kaltim & $100 \%$ & - & \\
\hline Jurnal ke-7 & $\begin{array}{l}\text { RSUD } \\
\text { Purworejo }\end{array}$ & & & $1,8 \%$ \\
\hline Jurnal ke-8 & Rumah Sakit “A” Bandung & $66,48 \%$ & $8,11 \%$ & $25,41 \%$ \\
\hline Jurnal ke-9 & $\begin{array}{l}\text { Rumah Sakit Bhayangkara Sartika } \\
\text { Asih Bandung }\end{array}$ & $50 \%$ & & $50 \%$ \\
\hline Jurnal ke-10 & Rumah Sakit Panti Waluya & $85 \%$ & & $15 \%$ \\
\hline
\end{tabular}

Dari tabel 2. dapat disimpulakan tingkat kepatuhan perawat dalam melakukan Assessment risiko pasien jatuh dari 10 jurnal yang di review, 9 jurnal mayoritas perawat sudah patuh dan hanya 1 jurnal yang mayoritas perawat belum patuh yaitu di RS X Surabaya.

\section{Upaya pencegahan risiko pasien jatuh di rawat} inap

Pencegahan risiko jatuh dapat menurunkan angka insiden jatuh di rumah sakit khususnya di instlasi rawat inap berdasarkan 10 artikel, terdapat beberapa pencegahan yang dilakukan sebagai berikut :

Tabel 3. Hasil Upaya pencegahan risiko pasien jatuh di rawat inap dari 10 jurnal

\begin{tabular}{|c|c|c|}
\hline Jurnal & Rumah Sakit & Upaya Pencegahan Risiko Jatuh \\
\hline Jurnal ke-1 & $\begin{array}{l}\text { Rumah Sakit Bhakti Wira } \\
\text { Tamtama Semarang. }\end{array}$ & $\begin{array}{l}\text { melakukan intervensi seperti menempatkan bel panggilan dalam } \\
\text { jangkauan pasien, memastikan label resiko jatuh terpasang di kamar/ } \\
\text { tempat tidur dan memberikan tentang resiko jatuh pada } \\
\text { pasien,memberikan saran pada pasien minta bantuan jika ada } \\
\text { kesulitan dan memasang tali pengaman bila diperlukan. }\end{array}$ \\
\hline Jurnal ke-2 & Rumah Sakit X Surabaya & $\begin{array}{l}\text { kepatuhan perawat dalam melaksanakan SPO Assessmen dan } \\
\text { Assesmen } \\
\text { Pasien Resiko Jatuh dan SPO Pemasangan Stiker Pasien Resiko } \\
\text { Jatuh di Rumah Sakit X }\end{array}$ \\
\hline Jurnal ke-3 & RS Santo Borromeus & 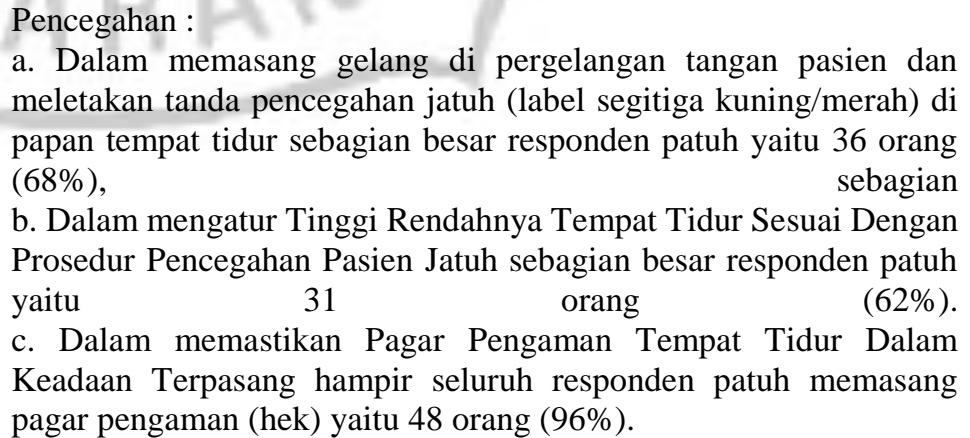 \\
\hline
\end{tabular}




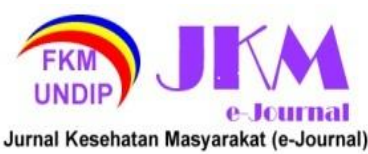

\begin{tabular}{|c|c|c|}
\hline Jurnal ke-4 & $\begin{array}{l}\text { Rumah } \quad \text { Sakit Umum } \\
\text { Daerah } \\
\text { Samarinda }\end{array}$ & $\begin{array}{l}\text { perawat memiliki pengetahuan yang baik mengenai pencegahan } \\
\text { risiko jatuh pada pasien, yaitu dengan memasang pagar pengaman } \\
\text { pada tempat tidur pasien serta dengan memberi tanda fall risk pada } \\
\text { pasien berisiko jatuh tinggi. }\end{array}$ \\
\hline Jurnal ke-5 & $\begin{array}{l}\text { RS Universitas } \\
\text { Maret }\end{array}$ & $\begin{array}{l}\text { Upaya pencegahan risiko yang dilakukan yaitu, kepatuhan perawat } \\
\text { dalam pelaksanaan pengkajian risiko jatuh }\end{array}$ \\
\hline Jurnal ke-6 & RS Pupuk Kaltim & $\begin{array}{l}\text { Hasil observasi fasilitas dalam rangka penerapan pencegahan pasien } \\
\text { risiko jatuh yang dilakukan di ruang perawatan dan UGD RS Pupuk } \\
\text { Kaltim, diketahui masih terdapat tempat tidur yang tidak bisa diatur } \\
\text { tinggi rendahnya dan tidak berpagar pengaman pada perawatan kelas } \\
\text { tiga, dan pasien perawatan kelas tiga tidak mendapatkan alas kaki } \\
\text { anti licin selama dirawat di RS Pupuk Kaltim }\end{array}$ \\
\hline
\end{tabular}

JURNAL KESEHATAN MASYARAKAT (e-Journal)

Volume 10, Nomor 1, Januari 2022

ISSN: 2715-5617 / e-ISSN: 2356-3346

http://ejournal3.undip.ac.id/index.php/jkm
Pelaksanaan program manajemen risiko jatuh pasien merupakan upaya yang dilakukan untuk mencegah maupun menangani pasien dengan risiko jatuh di RSUD Dr.

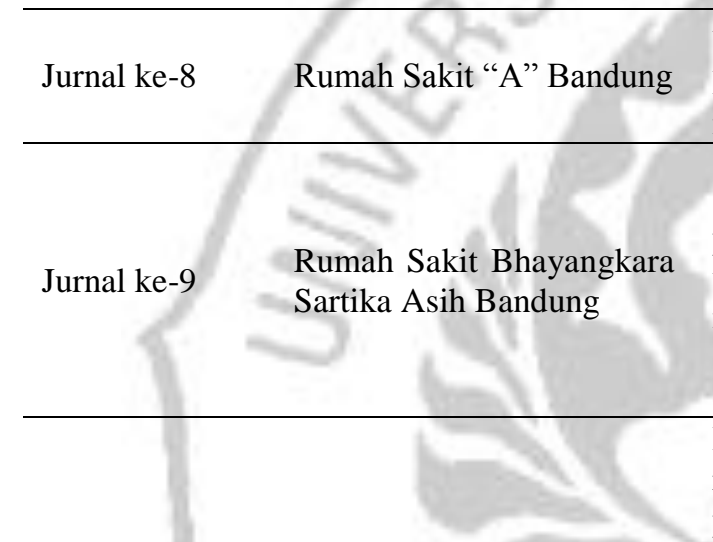

Jurnal ke-10 Rumah Sakit Panti Waluya

Upaya yang dilakukan yaitu mengidentifikasi Risiko Pasien Jatuh Dengan Menggunakan Skala Jatuh Morse. Setelah diperoleh nilainya maka akan dipasang kode jatuh

Sikap perawat yang bekerja kurang memiliki kesadaran tinggi pentingnya menggali ilmu dan informasi tentang keselamatan pasien terutama pencegahan jatuh pada pasien melalui media massa atau media elektronik dan masih terpaku pada pelatihan yang diikutinya, Selain itu pelatihan mengenai pencegahan pasien jatuh belum diikuti oleh semua perawat.

Dari hasil wawancara perawat telah melaksanakan SOP pencegahan risiko jatuh dengan baik. perawat kurang melakukan tindakan pencegahan risiko jatuh terutama dalam hal membuat jadwal pasien untuk kekamar mandi dan kurang memperhatikan pada saat mendekatkan bel pasien untuk pasien yang membutuhkan pertolongan / bantuan dan tidak memastikan dulu lantai tidak licin di kamar mandi

Berdasarkan Tabel 3. Hasil Upaya pencegahan risiko pasien jatuh di rawat inap dari 10 jurnal yang di review 2 jurnal menyatakan pencegahan jatuh yang dilakukan yaitu menempatkan bel panggilan dalam jangkauan pasien ${ }^{11,12} 2$ Jurnal mengatakan memastikan label (segitigiga kuning / merah) resiko jatuh terpasang di kamar/ tempat tidur, memasang tali pengaman beri tanda pencegahan jatuh dengan memasang label segitiga kuning/merah) di papan tempat tidur pasien 11,13. 2 jurnal mengatakan mengatur tinggi rendahnya tempat tidur dapat diatur dan sesuai dengan prosedur pencegahan pasien jatuh 11,14 . 2 jurnal mengatakan memastikan pagar pengaman tempat tidur selalu dalam keadaan terpasang ${ }^{13,15}, 1$ jurnal mengatakan menggunakan alas kaki anti licin ${ }^{12}, 1$ jurnal mengatakan memberi tanda fall risk pada pasien berisiko jatuh tinggi ${ }^{15}, 2$ jurnal menyatakan pencegahan jatuh yang dilakukan yaitu sebagai bentuk kepatuhan SOP yaitu melakukan Assessment dan Assessment ulang yaitu mengidentifikasi dengan Skala jatuh Morse ${ }^{16,17}$. 1
Jurnal menyatakan cara pencegahan yang dilakukan yaitu perawat patuh dalam pelaksanaan pengkajian risiko jatuh ${ }^{18}, 1$ Jurnal menyatakan upaya pencegahan risiko jatuh yang dilakukan yaitu Pelaksanaan program manajemen risiko jatuh pasien oleh perawat 19. Dan 2 jurnal menyebutkan pencegahan risiko pasien jatuh belum berjalan dengan baik karena Sikap perawat yang bekerja kurang memiliki kesadaran tinggi pentingnya menggali ilmu dan informasi tentang keselamatan pasien terutama pencegahan jatuh pada pasien melalui media massa atau media elektronik dan masih terpaku pada pelatihan yang diikutinya, Selain itu pelatihan mengenai pencegahan pasien jatuh belum diikuti oleh semua perawat ${ }^{9}$, sedangkan jurnal satunya menyatakan perawat kurang melakukan tindakan pencegahan risiko jatuh terutama dalam hal membuat jadwal pasien untuk kekamar mandi dan kurang memperhatikan pada saat mendekatkan bel pasien untuk pasien yang membutuhkan pertolongan / bantuan dan tidak 


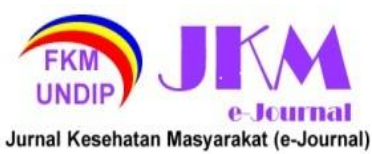

memastikan dulu lantai tidak licin di kamar mandi 12

Dalam pelaksanaan Assessment dari hasil diatas, peneliti mengamati 9 jurnal menyatakan perawat mayoritas sudah patuh melaksanakan Risk Assessment terhadap pasien yang berisiko jatuh di instalasi rawat inap meskipun masih ada beberapa perawat yang belum melakukan. Hasil penelitian ini sejalan dengan penelitian yang berjudul Pelaksanaan Program Manajemen Pasien dengan Risiko Jatuh Pasien di Rumah Sakit yang dilakukan oleh Sugeng Budiono Arief Alamsyah, Tri Wahyu S pada Januari 2013 di rumah sakit Islam Unisma Malang yang menyatakan bahwa sebagian besar perawat telah melaksanakan pencegahan risiko jatuh ${ }^{20}$.

Akan tetapi 1 jurnal menyatakan mayoritas perawat di rumah sakit belum patuh melaksanakan Risk Assessment terhadap pasien berisiko jatuh di RS X Surabaya karena menurut hasil penelitian Ni Panjawi terdapat faktor demografi yaitu usia dan faktor motivasi memiliki hubungan signifikan dengan kepatuhan pelaksanaan SPO Pencegahan Pasien Jatuh dan juga Motivasi dari 47 perawat termasuk dalam kategori rendah yaitu sebanyak 32 perawat $(68,1 \%)^{17}$

Dalam upaya pencegahan risiko pasien jatuh dari 10 Jurnal Review yang diamati oleh peneliti ada beberapa pencegahan risiko jatuh yang dilakukan oleh tiap tiap rumah sakit. Jika menggunakan teori ${ }^{21}$ pencegahan risiko jatuh dari jurnal review dapat digolongkan menjadi 3 cara pencegahan dan dapat diantisipasi dengan melaksanakan beberapa prosedur .

Pertama preventing accidental fall, dapat diantisipasi dengan melaksanakan beberapa prosedur yaitu menempatkan bel panggilan dalam jangkauan pasien, memastikan label resiko jatuh terpasang di kamar/ tempat tidur dan memberikan tentang resiko jatuh pada pasien ${ }^{15}$, memasang tali pengaman ${ }^{2213}$, memasang gelang identifikasi pasien resiko jatuh berwarna kuning pada pergelangan pasien, , menuliskan di whiteboard pada nurse station, mengatur tinggi rendahnya tempat tidur sesuai dengan prosedur pencegahan pasien jatuh, memastikan pagar pengaman tempat tidur dalam keadaan terpasang ${ }^{13}$. Kedua preventing anticipated physiological falls, dapat diantisipasi dengan melaksanakan prosedur memberikan alat bantu jalan seperti kursi roda/Bedrest/kruk/tongkat/walker ${ }^{13}$. Ketiga preventing unanticipated physiological falls dapat diantisipasi dengan melaksanakan beberapa prosedur yaitu melakukan Risk Assessment baik Assessment awal maupun Assessment ulang, membuat SOP terkait pencegahan risiko pasien jatuh.

\section{KESIMPULAN}

Dari 10 jurnal yang direview 9 jurnal mengatakan perawat di rumah sakit sudah patuh dan melakukan Risk Assessment pasien, baik Assessment awal dan Assessment ulang / Re-Assessement. dan 1 jurnal mengatakan mayoritas perawat belum patuh dalam pelaksanaan Risk Assessment. Dan Dalam pencegahan pasien risiko jatuh rumah sakit sudah menerapkan beberapa prosedur yang harus dilakukan dalam upaya pencegahan pasien berisiko jatuh seperti memasang gelang identifikasi pasien resiko jatuh berwarna kuning pada pergelangan pasien, mengatur tinggi rendahnya tempat tidur sesuai dengan prosedur pencegahan pasien jatuh, melakukan pengkajian dan penilaian risiko jatuh, melaksanakan SOP Pencegahan risiko jatuh, dsb.

Berdasarkan pada pengalaman langsung peneliti dalam proses penelitian ini, ada beberapa keterbatasan yang dialami dan dapat menjadi beberapa faktor yang agar dapat untuk lebih diperhatikan bagi peneliti-peneliti yang akan datang dalam lebih menyempurnakan penelitiannya karna penelitian ini sendiri tentu memiliki kekurangan yang perlu terus diperbaiki dalam penelitianpenelitian kedepannya.

\section{SARAN}

Saran bagi perawat di seluruh rumah sakit diharapkan selalu patuh dalam melakukan langkah awal dalam pencegahan risiko jatuh yaitu Assessment awal dan Assessment ulang dan juga melakukan pencegahan risiko jatuh yang tepat dan sesuai dengan hasil penilain Assessment. Saran bagi pihak rumah sakit / kepala perawat perlu meningkatkan fungsi pengawasan dan kontroling terhadap kepatuhan perawat dalam melakukan Assessment dan pencegahan terhadap risiko pasien jatuh, mensosialisasikan pentingnya melakukan Assessment dan pencegahan pasien jatuh dan diharapkan memberikan pelatihan, bimbingan dan motivasi secara berkala kepada perawat sehingga dalam melaksanakan pencegahan risiko jatuh menjadi lebih baik. Dan saran bagi penelitian selanjutnya Peneliti selanjutnya diharapkan dapat mengembangkan penelitian ini dengan melihat faktor faktor lain yang belum upaya pencegahan risiko pasien jatuh.

\section{DAFTAR PUSTAKA}

1. Permenkes 2017. Permenkes 11 Tahun 2017. Peratur Menteri Kesehat Republik Indones No 11 Tahun 2017 Tentang Keselam Pasien. 2017;4:9-15.

2. Lloyd 2011. Pencegahan Resiko Jatuh. J Chem Inf Model. 2010;53(9):1689-1699.

3. Putrina, Ade 2019. Analisis Perilaku Kepatuhan Perawat Dalam Re-Assesment Pasien Risiko Jatuh Dengan Pendekatan Theory Of Planned 


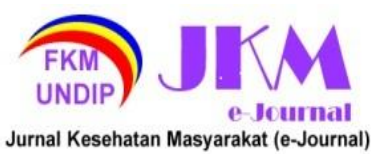

Behavior Di RSUD DR. Soetomo Surabaya. Vol 53.; 2019.

4. Miake-Lye IM, Hempel S, Ganz DA, Shekelle PG. Inpatient fall prevention programs as a patient safety strategy: a systematic review. Ann Intern Med. 2013;158(5_Part_2):390-396.

5. Bouldin ED, Andresen EM, Dunton NE, et al. Falls among Adult Patients Hospitalized in the United States: Prevalence and Trends. J Patient Saf. 2013;9(1):13-17. doi:10.1097/PTS.0b013e3182699b64

6. JCI. Joint Commission International (JCI), (2011) Standar Akreditasi Rumah Sakit: Enam Sasaran Keselamatan Pasien. Edisi Ke-4. Jakarta.; 2011.

7. Putrina, Ade dkk 2019. FUNDAMENTAL AND MANAGEMENT Kepatuhan Perilaku Perawat dalam Re-Assessment Pasien Resiko Jatuh dengan Pendekatan Theory of Planned Behaviour ( Compliance of the Nurse for Fall Risk Re-Assessment Base on Theory of Planned Behaviour ). 2019;2(2):45-54

8. Ginting R. Pentingnya melakukan pelaksanaan langkah - langkah menuju keselamatan pasien dalam mencegah resiko jatuh di rumah sakit. Published online 2019. doi:10.31219/osf.io/9rhnq

9. Rahmat, Nandang Jamiat Nugraha YMJ. Hubungan Pengetahuan Denga Sikap Perawat Dalam Pencegahan Pasien Jatuh Di Ruang Rawat Inap RS. 2020;8(1):11-22.

10. Nur HA, Dharmana E, Santoso A. Pelaksanaan Asesmen Risiko Jatuh di Rumah Sakit The Implementation of Falls Risk Assessment InThe Hospital. J Ners dan Kebidanan Indones. 2016;5(2):123-133.

11. Nurhayati S, Rahmadiyanti M, Hapsari S, Karya S, Semarang H. Kepatuhan Perawat Melakukan Assessment Resiko Jatuh Dengan Pelaksanaan Intervensi Pada Pasien Resiko Jatuh. J Ilm Keperawatan Stikes Hang Tuah Surabaya. 2020;15(2).

12. Kristiana Catur I. the Relationship of Nurses' Knowledge About Patient Safety in Risk Prevention of Falling With the Implementation Ofstandard Operating Procedures (Sop) of Falling Risk Prevention in Adult Inpatient Room Panti Waluya Malang. Nurs News (Meriden). 2018;3:785-790.

13. Setyarini EA, Herlina LL. Kepatuhan perawat melaksanakan standar prosedur operasional: pencegahan pasien resiko jatuh Digedung Yosef 3 Dago dan Surya Kencana Rumah Sakit Barromeus. Kesehat Stikes St Barromeus. Published online 2013:94-105.

14.Sanjaya PD, Rosa EM, Ulfa M. Evaluasi Penerapan Pencegahan Pasien Berisiko Jatuh di Rumah Sakit. Kes Mas J Fak Kesehat Masy.
2018;11(2):105-113.

doi:10.12928/kesmas.v11i2.6013

15.Faridha NRD, Milkhatun. Hubungan Pengetahuandengan Kepatuhan Perawat dalam PelaksanaanPencegahan Pasien Jatuh di Rumah SakitUmum Daerah Pemerintah Samarinda. Borneo Student Res. 2020;1(3):1883-1889.

16. Elizabeth Ari Setyarini. Pelaksanaan Standar Prosedur Operasional: Identifikasi Resiko Pasien Jatuh Dengan Menggunakan Skala Jatuh Morse Di Rumah Sakit "a" Bandung. Stikes. 2010;1:1-12.

17. Jati NPL. kepatuhan Perawat melaksanakan Standar Prosedur Operasioinal pencegahan Pasien Jatuh berdasarkan Faktor Demografi Dan Motivasi. J Ilm Kesehat Media Husada. 2018;6(2):225-264. doi:10.33475/jikmh.v6i2.44

18.Deviyana S, Safitri W, Syolihan D, et al. Hubungan Pengetahuan dengan Kepatuhan Perawat dalam pelaksanaanpencegahan Pasien Jatuh di Rumah sakitumum Daerah Pemerintah Samarinda. 2020;64.

19. Warihwirawan R. Hubungan Pengetahuan Dengan Kepatuhan Perawat Dalam Melaksanakan Standar Prosedur Operasional Risiko Pasien Jatuh Di Ruang Rawat Inap Dewasa Rsud Dr. Tjitrowardojo Purworejo. 2017;(1).

20.Sugeng Budiono, Arief Alamsyah TWS. Pelaksanaan Program Manajemen Pasien dengan Risiko Jatuh di Rumah Sakit. J Chem Soc Perkin Trans 1. 2014;28(18):6. doi:10.1039/p19920002253

21. Morse, Janice M 2008. Preventing Patient Falls. Springer Publishing Company; 2008.

22.Nurhayati S, Rahmadiyanti M, Hapsari S. Kepatuhan Perawat Melakukan Assessment Resiko Jatuh Dengan Pelaksanaan Intervensi Pada Pasien Resiko Jatuh Susi Nurhayati, Merlinda Rahmadiyanti, Shindi Hapsari STIKes Karya Husada Semarang Email: susinurhayati74@yahoo.com Corresponding Author : susinu. 2020;15(2):278-284. 